Bangladesh J. Zool. 41(1): 73-78, 2013

\title{
HETEROTROPHIC ACTIVITIES IN EUTROPHIC LAKE SEDIMENT BY INDIGENOUS BACTERIUM BACILLUS FIRMUS
}

\author{
Md. Abdul Karim*, Nazneen Akhter and Sirajul Hoque ${ }^{1}$ \\ Laboratory of Microbiology, Department of Botany, University of Dhaka, \\ Dhaka-1000, Bangladesh
}

\begin{abstract}
Bacterial isolates, Bacillus firmus (LS-31) were collected from eutrophic Gulshan lake, Dhaka sediments and introduced to stimulate inorganic nutrient regeneration in the laboratory. The bacteria stimulated net regeneration of dissolved inorganic nitrogen and inorganic phosphorus in the water by about two folds at both the incubation temperatures $\left(26^{\circ} \mathrm{C}\right.$ and $\left.30^{\circ} \mathrm{C}\right)$. These results suggest that the application of $B$. firmus would be promising for the stimulation of inorganic nutrient regeneration at the eutrophic environment.
\end{abstract}

Key words: Bacillus firmus, Heterotrophic activity, Eutrophic environment.

\section{INTRODUCTION}

The maintenance of water quality means that natural waters cannot be overloaded with organic or inorganic nutrients or with toxic, noxious, or esthetically unacceptable substances. They should not become vehicles of disease transmission from fecal contamination nor should their oxygenation, temperature, salinity, turbidity or $\mathrm{pH}$ be altered significantly. Liquid wastes, produced by everyday human activities (domestic sewage) and by various agricultural and industrial operations, following drainage patterns or sewers, enter natural bodies of surface water, such as rivers, lakes and oceans. People use the same water bodies in alternative ways: as sources of drinking, household, industrial, irrigation, fish production and other recreational activities (Atlas and Bartha 1998).

The most common water quality problems in such systems are oxygen depletion and accumulation of organic matter, inorganic nitrogen, particularly ammonia, and carbon dioxide (Muir 1982). Transformation of ammonia excreted by the fish and liberated by decomposition of uneaten feed and fish faces, takes place through the biological processes of algal assimilation, ammonification and nitrification (Rijn et al. 1984). Ammonia in the water column is assimilated and immobilized by algae. The ammonia accumulates in the sediment under anoxic conditions and is oxidized to nitrate by autotrophic nitrifying bacteria under oxic

*Corresponding author: makarim10@yahoo.com

${ }^{1}$ Department of Soil, Water and Environment, University of Dhaka, Dhaka 1000, Bangladesh

conditions. Renewed anoxic condition and presence of high nitrate concentrations in the pond sediment results in the development of denitrifying population. 
Diab and Shilo (1986) and Hopkins et al. (1994) mentioned that heterotrophic bacteria uses organic degradation products as source of carbon and energy and nitrate as an electron acceptor, dissimilate nitrate under anoxic conditions, via nitrate, nitric oxide and nitrous oxide to gaseous elemental nitrogen, which is subsequently released into the atmosphere.

Stimulation of heterotrophic activities using bacterial isolates that are metabolically more active may be a possible way. Considering above situation and facts, present work was undertaken to assses the role of a bacterial isolate to improve the water quality of an europhic lake by enhancing decomposition of organic pollutants.

\section{MATERIAL AND METHODS}

Isolation and selection of bacteria: For isolation of effective bacteria that might be active at high temperature, surface water and sediment sample were collected twice (September 26 and October 2, 2009) from the Gulshan lake during summer when the temperature was between $26^{\circ} \mathrm{C}-30^{\circ} \mathrm{C}$. After returning to the laboratory, $1 \mathrm{~g}$ of sediment sample was added to $100 \mathrm{ml}$ of sterile distilled water and mixed it well and from which $1 \mathrm{ml}$ of sediment suspension was inoculated into each of 10 test tubes containing $10 \mathrm{ml}$ of nutrient broth medium and incubated at $37^{\circ} \mathrm{C}$ for 48 hours. One $\mathrm{ml}$ of bacterial culture from each inoculated tube was transferred into new nutrient broth medium. It was continued until 4 times to enrich the bacteria. Finally, $0.1 \mathrm{ml}$ of bacterial culture from each tube was inoculated onto nutrient agar plates, and incubated at $37^{\circ} \mathrm{C}$. Eighty fast growing bacterial isolates were isolated from the surface sediment of the study sites. Considering growth pattern, high metabolic activities and colony

morphology, bacterial isolate LS-31 was selected to use in the present experiment.

Inocula preparation and incubation: Bacterial broth culture was centrifuged at $10,000 \mathrm{rpm}$ (Himac CR 21E, Hitachi) for 10 minutes at $10^{\circ} \mathrm{C}$. The supernatant was discarded and bacterial cells plate was gently rinsed with sterilized water at least five times in order to remove associated nutrients and re-suspended with the same sterilized water by pipetting. Five $\mathrm{ml}$ of bacterial cell re-suspension was used as inocula and it was inoculated into the water sample containing treatment glass bottle.

The glass bottles were incubated in a light condition in situ (in duplicate) at $26^{\circ} \mathrm{C}$ temperature during September 2010 and at $30^{\circ} \mathrm{C}$ during October 2010 for 15 days without any shaking to estimate bacterial activities. Bacterial activities were evaluated by the changes of inorganic nutrient regeneration into the water during incubation with or without adding bacteria. 
Sub-sampling and nutrient analysis: Just after adding bacteria two glass bottles where one for control and another with bacteria (in duplicate) were taken at the beginning of the incubation (0-day). At 5 days interval up to 15 days, two glass bottles (in duplicate) were taken without any disturbance of the system and analyzed for chemical changes.

For chemical analysis, water samples were passed through the filter paper (Whatman No. 42, England) to eliminate suspended solid particles. The concentrations of inorganic form of nitrogen (DIN) ammonium, nitrate and nitrite and phosphorus (DIP) were measured by the following standard methods.

Morphological, cultural, physiological and biochemical studies of the isolate: Important morphological, physiological and biochemical characteristics were studied for the identification of the selected isolate. Morphological studies were performed by simple, gram and spore staining and observed under phase contrast microscope at 10X to 100X. Different biochemical tests were carried out following Bergey's Manual (Sneath et al. 1986), Manual of Microbiological Methods (SAB 1957), Microbiological Methods (Collins and Lyne 1984) and Understanding Microbes (Claus 1995).

\section{RESULTS AND DISCUSSION}

Growth curve of bacteria: The isolate LS-31 exhibited remarkably high growth rates between $30^{\circ} \mathrm{C}$ and $40^{\circ} \mathrm{C}$ but didn't grow well at relatively low $\left(10^{\circ} \mathrm{C}\right)$ and high temperature $\left(50^{\circ} \mathrm{C}\right)$ and was considered to be mesophilic (Fig. 1). In regard to proteolytic activities, LS-31 possessed high activities by clear zone into the medium and increased with incubation period (Fig. 2). By considering growth curve and proteolytic activities, bacterial isolate of LS-31 was selected for further study.

Identification of LS-31 isolate: For identification of the strain LS-31, morphological characteristics of the bacterium, such as cell shape, colony characteristics, pigmentation etc. were investigated. Different physiological and biochemical characteristics such as gram reaction, catalase test, oxidase test, indole formation, citrate utilization, Voges Proskauer (VP) test. MR test, oxidation fermentation test, acid from D-glucose, L-arabinose, D-xylose and Dmannitol were also recorded (Table 1) and compared with the standard description in different Manuals (Sneath et al. 1986, SAB 1957, Collins and Lyne 1984, and Claus 1995).

The isolate LS-31 showed positive results in gram reaction, catalase test, MR test, protease test, $\mathrm{KOH}$, tyrosine degradation, egg yolk lecithinase, motility test, hydrolysis of starch, gelatin and casein. However, it showed negative results in 
Table 1. Morphological, physiological and biochemical characteristics of bacterial isolate LS-31

\begin{tabular}{|c|c|c|c|c|c|c|}
\hline \multicolumn{2}{|c|}{ Characteristics } & Results & \multicolumn{2}{|c|}{ Characteristics } & Results & $\begin{array}{c}\text { Provisional } \\
\text { Identification }\end{array}$ \\
\hline \multicolumn{2}{|c|}{ Gram reaction } & + & \multicolumn{2}{|l|}{$\mathrm{KOH}$} & + & \multirow{14}{*}{$\begin{array}{l}\text { Bacillus } \\
\text { firmus }\end{array}$} \\
\hline \multicolumn{2}{|l|}{ Cell } & $\begin{array}{l}\text { Short rod, } \\
\text { occur in chain } \\
\text { and singly }\end{array}$ & \multicolumn{2}{|c|}{ Utilization of citrate } & - & \\
\hline \multicolumn{2}{|l|}{ Spore } & $\begin{array}{c}\text { Ellipsoidal, } \\
\text { central }\end{array}$ & \multicolumn{2}{|c|}{ Utilization of propionate } & - & \\
\hline \multicolumn{2}{|l|}{ Catalase } & + & \multicolumn{2}{|c|}{ Indole formation } & - & \\
\hline \multicolumn{2}{|l|}{ Oxidase } & - & \multicolumn{2}{|c|}{ Dihydroxy acetone production } & - & \\
\hline \multicolumn{2}{|l|}{ VP } & - & \multirow{4}{*}{$\begin{array}{l}\text { Fermen- } \\
\text { tation }\end{array}$} & D-glucose (no gas) & - & \\
\hline MR & & + & & L-arabinose & + & \\
\hline Levan & & - & & D-xylose & - & \\
\hline $\begin{array}{l}\text { Phenayal } \\
\text { deaminase }\end{array}$ & anine & - & & D-mannitol & + & \\
\hline Protease & & + & \multicolumn{2}{|c|}{ Degradation of tyrosine } & + & \\
\hline Motility & & + & \multicolumn{2}{|c|}{ Nitrate reduction } & - & \\
\hline \multirow[t]{3}{*}{ Hydrolysis } & Starch & + & \multicolumn{2}{|c|}{ Egg yolk lecithinase } & + & \\
\hline & Casein & + & \multirow{2}{*}{\multicolumn{2}{|c|}{ Egg yolk lipase }} & - & \\
\hline & Gelatin & + & & & Aerobic & \\
\hline
\end{tabular}

'+' and '-' marks denote positive and negative, respectively

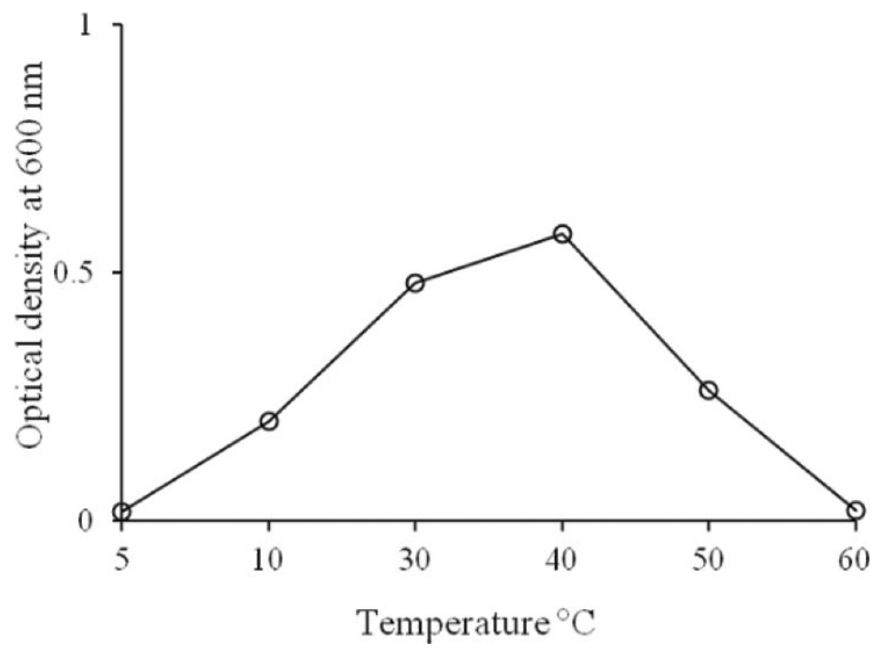

Fig. 1. Growth of LS-31 bacterial isolate at different temperatures

oxidase test, VP test, levan test, nitrate reduction, phenylalanine deamination, utilization of propionate and citrate, egg yolk lipase, indole formation and dihydroxy acetone production. In case of hydrolysis of different carbohydrates the strain could produce acid from L-Arabinose and D-Mannitol, but couldn't hydrolyze D-Glucose and D-Xylose (Table 1). Considering the morphological, cultural, physiological and biochemical characteristics, we tentatively identified the isolate LS-31 as B. firmus. 


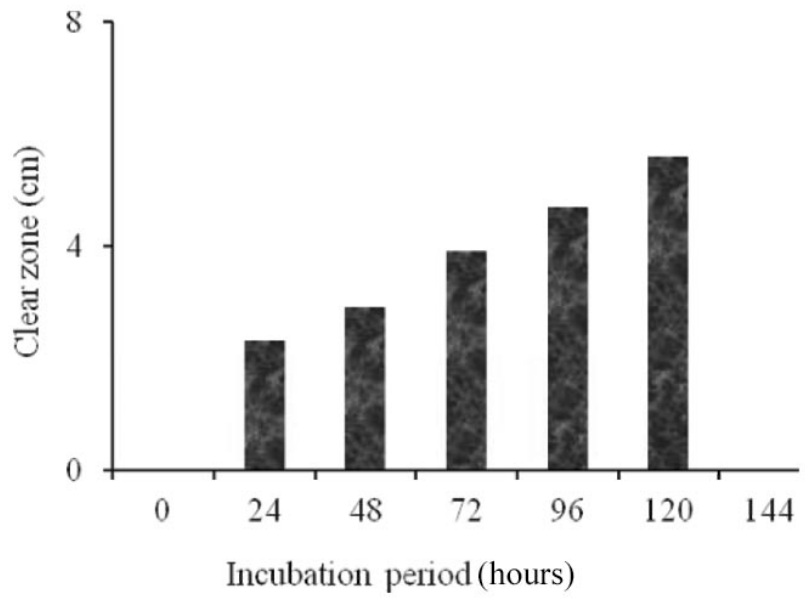

Fig. 2. Proteolytic activity of the bacterial isolate (LS-31) at different hours of incubation

Net release of Dissolved Inorganic Nitrogen (DIN) and Dissolved Inorganic Phosphorus (DIP): Two experiments were carried out using the bacterial strain $B$. firmus. The water samples incubated at in situ temperature of $26^{\circ} \mathrm{C}$, the net releases of DIN and DIP in control counterparts (without adding bacteria) were $28.22 \mathrm{mg} / 1$ and $0.57 \mathrm{mg} / 1$, respectively (Fig. 3). But after addition of B. firmus, the net releases of DIN $(41.25 \mathrm{mg} / \mathrm{l})$ and DIP $(1.03 \mathrm{mg} / \mathrm{l})$ were prominently higher compared to the control (Fig. 3).
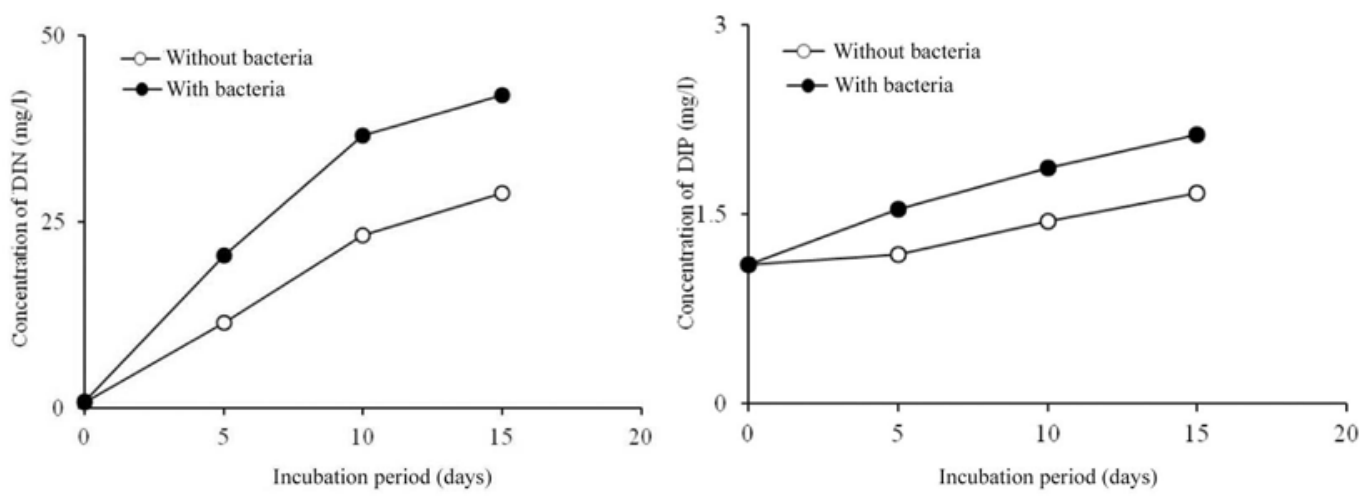

Fig. 3. Concentration of dissolved inorganic nitrogen (DIN) and dissolved inorganic phosphorus (DIP) in the Bacillus firmus added and control water samples incubated at $26^{\circ} \mathrm{C}$ temperature

When water samples were incubated in situ at $30^{\circ} \mathrm{C}$, the net releases of DIN and DIP in the $B$. firmus supplemented were found significantly higher compared to the control. Net releases of DIN $(35.10 \mathrm{mg} / \mathrm{l})$ and DIP $(1.56 \mathrm{mg} / \mathrm{l})$ in the experiment with addition of $B$. firmus (Fig. 4). 

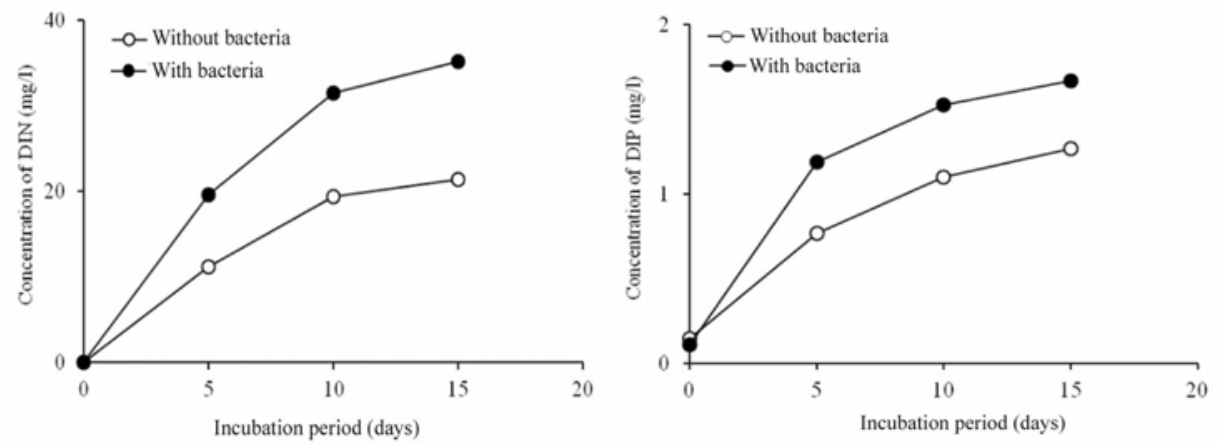

Fig. 4. Concentration of dissolved inorganic nitrogen (DIN) and dissolved inorganic phosphorus (DIP) in the Bacillus firmus. added and control water samples incubated at $30^{\circ} \mathrm{C}$ temperature,

The results of the present experiment demonstrate that organic as well as inorganic pollutants of the fresh water many be reduced by decomposing the utilizing effective bacterial isolate. It is necessary to conduct further study regarding the removal of enhanced inorganic nutrients from the eutrophic water.

\section{LITERATURE CITED}

ATLAS, R.M. and BARTHA, R. 1998. Microbial Ecology (4th ed.). Addison Wesley Longman, Inc. California. pp. 499-503.

CLAUS, G.W. 1995. Understanding Microbes. (4th ed.). W.H. Freeman and Company, New York. p. 547.

COLLINS, C.H. and LYNE, P.M. 1984. Microbiological Methods (5 $5^{\text {th }}$ ed.). Butterworth and Co. (Publishers) Ltd., London. pp. 102-113.

DIAB, S. and SHILO, M. 1986. Transformation of nitrogen in sediments of fish ponds in Israel. Bamidgeh. 38: 67-88.

HOPKINS, S.J., SANDIFER, P.A. and BROWDY, C.L. 1994. Sludge management in intensive pond culture of shrimp: Effect of management regime on water quality, sludge characteristics, nitrogen extinction, and shrimp production. Aquacult. Eng. 13: 11-30.

MUIR, J.F. 1982. Recirculated water systems in aquaculture. In: Muir, J.F. and Roberts, R.J. (eds.). Recent Advances in Aquaculture. Westview Press, Boulder, Co. pp. 357-447.

RIJN, V.J., DIAB, S. and SHILO, M. 1984. Mechanisms of ammonia transformations in fish ponds. In: Rosenthal, H. and Sarig, S. (eds.). Research on Aquaculture. Spec.Publ. No. 8, European Mariculture Society, Bredene, Belgium. pp. 17-40.

SAB (Society of American Bacteriologists) 1957. Manual of Microbiological Methods. McGraw-Hill Book Co. Inc. NY. pp. 1-315.

SNEATH, P.H.A., MAIR, N.S., SHARPE, M.E. and HOLT, J.G. (eds.) 1986. Bergey's Manual of Systematic Bacteriology (9th ed). Vol. 2. The Williams and Wilkins Co., Baltimore, USA. pp. 9651594. 